\title{
Influence of body mass index on the frequency of lymphedema and other complications after surgery for breast cancer
}

\author{
Influência da massa corporal na frequência de linfedema e outras complicações \\ depois de cirurgia para câncer de mama
}

Influencia del indice de masa corporal en la frecuencia de linfedema y otras complicaciones después de la cirugía para el cáncer de mama

Riza Rute Oliveira', Simony Lira Nascimento², Maria Teresa Pace do Amaral³, Marcela Ponzio Pinto e Silva ${ }^{4}$, Mariana Maia Freire Oliveira ${ }^{4}$

\begin{abstract}
I Objective: this study assessed the influence of pre-operative body mass index (BMI) has upon lymphedema, scar tissue adhesion, pain, and heaviness in the upper limb at two years after surgery for breast cancer. Methods: retrospective analysis of 631 medical records of women who underwent surgery for breast cancer and were referred to the Physiotherapy Program at Prof. Dr. José Aristodemo Pinotti Women's Hospital of the Center for Integral Women's Health Care, CAISM/ UNICAMP between January 2006 and December 2007. Results: mean age of women was 56.5 years ( \pm 13.7 years) and the most part (55\%) were overweight or obese, surgical stages II and III were present in 63\% of women studied. Radical mastectomy was the most frequent surgery (54.4\%), followed by quadrantectomy (32.1\%). In the first year after surgery, there was no significant association between BMI categories and incidence of scar tissue adhesion, pain, heaviness and lymphedema. In the second year, overweight and obese women had higher rates of heaviness in the upper limb and lymphedema. For lymphedema, there was a significant difference among BMI categories ( $p=0.0268$ ). Obese women are 3.6 times more likely to develop lymphedema in the second year after surgery (odds ratio $3.6195 \% \mathrm{Cl} 1.36$ to 9.41). Conclusion: $\mathrm{BMI} \geq 25 \mathrm{~kg} / \mathrm{m}^{2}$ prior to treatment for breast cancer can be considered a risk factor for developing lymphedema in the two years after surgery. There was no
\end{abstract}

association between BMI and the development of other complications.

Keywords: Breast Neoplasms/complications; Lymphedema; Body Mass Index; Risk Factors.

RESUMO I Avaliou-se a influência do índice de massa corporal (IMC) pré-operatória na ocorrência de linfedema, aderência cicatricial, dor e peso no membro superior nos primeiros dois anos após cirurgia para câncer de mama. O estudo é uma análise retrospectiva, secundária de 631 prontuários de mulheres submetidas à cirurgia para câncer de mama e encaminhadas ao Programa de Fisioterapia do Hospital Professor Dr. José Aristodemo Pinotti do Centro de Atenção Integral à Saúde da Mulher, CAISM /UNICAMP, entre janeiro de 2006 e dezembro de 2007. Eram mulheres com idade média de 56,5 anos ( $\pm 13,7$ anos), a maioria (55\%) com sobrepeso ou obesa. Os estádios clínicos II e III foram encontrados em 63\% das mulheres. Mastectomia radical foi a cirurgia mais frequente (54,4\%), seguida por quadrantectomia (32,1\%). No primeiro ano após a cirurgia não houve associação significativa entre as categorias do índice de massa corporal e incidência de aderência cicatricial, dor, peso e linfedema. No segundo ano, mulheres com sobrepeso e obesidade apresentaram maiores taxas de peso no membro superior e linfedema. Para linfedema houve diferença significativa entre as categorias de índice de massa corporal $(p=0,0268)$.

Study developed on University of Campinas (Unicamp) - Campinas (SP), Brazil.

'Graduate Program of Physiotherapy, Centro Universitário Adventista de São Paulo (UNASP) - São Paulo (SP), Brazil.

${ }^{2}$ Physiotherapy Department, Universidade Federal do Ceará (UFC) - Fortaleza (CE), Brazil.

${ }^{3}$ Management and Health Care Department, Universidade Federal de São Paulo (UNIFESP) - Santos (SP), Brazil.

${ }^{4}$ Physiotherapy Section - Prof. Dr. José Aristodemo Pinotti Women's Hospital - Integral Health Care Center (CAISM), Universidade

Estadual de Campinas (UNICAMP) - Campinas (SP), Brazil. 
Mulheres obesas têm 3,6 vezes mais chance de desenvolver linfedema no segundo ano após a cirurgia (odds ratio 3,61 95\% IC $1,36-9,41$ ). Concluiu-se que IMC $\geq 25 \mathrm{~kg} / \mathrm{m}^{2}$ anterior ao tratamento para câncer de mama pode ser considerado fator de risco para desenvolvimento do linfedema dois anos após a cirurgia. Não houve associação entre IMC e outras complicações.

Descritores: Neoplasias da Mama/complicações; Linfedema; Índice de Massa Corporal; Fator de Risco.

RESUMEN | Evaluación la influencia del índice de masa corporal preoperatorio, la aparición de linfedema, la adhesión de tejido cicatrizal, dolor y pesadez en los dos primeros años después de la cirugía para el cáncer de mama. Método: análisis retrospectivo de 631 historias clínicas de mujeres sometidas a cirugía para el cáncer de mama y encaminadas al Programa de Fisioterapia do Centro de Atención Integral de la Salud de la Mujer - Professor Dr. José Aristodemo Pinotti - CAISM / UNICAMP entre enero de 2006 y diciembre de 2007. Resultados: mujeres de mediana edad 56,5 años ( $\pm 13,7$ años), 55\% tenían sobrepeso u obesidad. Etapas II y III del cáncer se encontraron en el $63 \%$ de las mujeres. Cirugía de mastectomía radical fue la más frecuente (54,4\%), seguido de cuadrantectomía (32,1\%). En el primer año después de la cirugía no hubo asociación significativa entre categorías de índice de masa corporal y incidencia de la adhesión del tejido de cicatriz, dolor, peso y linfedema. En el segundo año, sobrepeso y obesidad tenían mayores tasas de peso y linfedema. Para linfedema hubo diferencias significativas entre categorías de índice de masa corporal ( $p=0,0268)$. Las mujeres obesas tienen 3,6 veces más probabilidades de desarrollar linfedema en el segundo año después de la cirugía (odds ratio 3,61 IC del 95\%: 1,36 a 9,41). La conclusión és índice de masa corporal $\geq 25 \mathrm{~kg} / \mathrm{m}^{2}$ antes del tratamiento para el cáncer de mama puede ser considerado un factor de riesgo para desarrollo de linfedema, dos años después de la cirugía. No hubo asociación entre el índice de masa corporal y otras complicaciones.

Palabras clave: Neoplasias de la Mama/complicaciones, Linfedema; Índice de Masa Corporal; Factores de Riesgo.

\section{INTRODUCTION}

Breast cancer is the most common cancer among women, with higher incidence in women between 50 and 60 years of age ${ }^{1}$. Early diagnosis, technological advances, more conservative surgery and new treatment modalities have increased the life expectancy of women with breast cancer. This improvement in life expectancy is contrasted with its impact on overall health, as breast cancer and its treatment can have a negative impact on women's lives ${ }^{2}$.

Breast alteration and arm disorders lead to lower quality of life 3 . Among the complications associated with breast cancer treatment, lymphedema is one of the most significant, with prevalence rates between 0 and $56 \%$, which may increase over time ${ }^{4,5}$. Diversity of diagnostic methods and follow-up time explain its wide range of occurrence.

Lymphedema is a chronic condition caused by the accumulation of protein-rich fluid in interstitial spaces. The diagnosis varies depending on the degree of limb swelling and other clinical signs and symptoms ${ }^{6}$. Although three quarters of women have symptoms within one to two years after surgery, onset may be insidious and risk is present for the rest of their lives ${ }^{7}$. Presently, there is no cure for lymphedema; as such, the identification of possible risk factors for this complication is paramount ${ }^{8}$.

Studies suggest that potential risk factors for developing lymphedema include radiation therapy, infection, axillary dissection, type of surgery, the number of lymph nodes removed and involved, and obesity. Even though it is not known whether these factors affect the severity of lymphedema ${ }^{6}$, obesity can be associated with increased chronic inflammation, fibrosis and adipose deposition ${ }^{9}$, therefore obese or overweight women are at higher risk for lymphedema. The purpose of this study was to investigate the influence of BMI of women who underwent survey with axillary dissection for breast cancer on the occurrence of lymphedema and other complications such as scar tissue adhesion, pain, and heaviness in the upper limb within two years after surgery.

\section{METHODOLOGY}

We performed a retrospective secondary analysis of the medical records of 707 women who underwent surgery for breast cancer and who were referred to the Physiotherapy Program of Prof. Dr. José Aristodemo Pinotti Women's Hospital of the Integral Healthcare 
Center, CAISM/UNICAMP between January 2006 and December 2007.

The original study was approved by the Research Ethics Committee of the School of Medicine of UNICAMP (no. 1096/2009). As this study employed medical record review, it was exempted from the requirements of patient consent.

To analyse the relationship between pre-operative BMI and postoperative complications, 631 medical records that had data on weight and height, enabled the calculation of BMI. These data were collected before surgery.

Women were classified according to BMI categories of the World Health Organization (WHO): underweight $\left(<18.5 \mathrm{~kg} / \mathrm{m}^{2}\right)$, normal range $(\geq 18.5$ and $\left.\leq 24.9 \mathrm{~kg} / \mathrm{m}^{2}\right)$, overweight $\left(\geq 25\right.$ and $\left.\leq 29.9 \mathrm{~kg} / \mathrm{m}^{2}\right)$ and obese $\left(\geq 30 \mathrm{~kg} / \mathrm{m}^{2}\right)^{10}$.

The postoperative complications analyzed were: dehiscence and scar tissue adhesion, pain (located in the arm, axilla or breast region), sensation of heaviness in the upper limb (UL) and lymphedema. The techniques used to identify scar defects were inspection and palpation, while arm circumference ${ }^{11}$ and palpation were used to identify lymphedema. Women's complaints of pain and heaviness in the UL were included in medical records.

Information about complications were collected from medical records at three time points after surgery: we sought information about dehiscence and scar tissue adhesion at the end of the fourth week, and information about adherence, pain and heaviness in the UL, as well as lymphedema in the first and second years after surgery.

A descriptive analysis was performed using means, standard deviation, and absolute and relative frequencies $(\% \mathrm{n})$ for epidemiological and clinical characteristics and for the presence of complications. To evaluate the association between BMI and postoperative complications, chi-square and Fisher exact tests were performed. $\mathrm{p}<0.05$ was considered statistically significant and for variables with significant associations, odds ratios were calculated to assess the magnitude of association.

\section{REHABILITATION PROGRAM}

On the first day after surgery, a physical therapist guides women to perform three upper body exercises: flexion, abduction and shoulder rotation. At hospital discharge, women received a booklet with guidelines about care of the ipsilateral arm and instructions to perform the exercises at home. The women received also the referral to the Rehabilitation Program, which has multidisciplinary team (physical therapist, nurse, psychologist and social assistant). On the first month after the surgery, women performed active group exercises (constituted approximately 19 exercises for the upper limb, containing stretching, active exercise and relaxation $)^{12}$, three times a week, lasting about an hour. At the end of the program, women are evaluated by a physical therapist and stimulated to nurse the ipsilateral upper limb.

\section{RESULTS}

Among the 707 medical records consulted, 513 (72.6\%) were from patients that joined the Rehabilitation Program and 76 were excluded because they lacked weight and height data used to calculate BMI before surgery. Among the other 631 women, 36 were underweight, 206 were normal range, 213 were overweight and 176 were obese. Throughout the first and second years after surgery, occurred a reduction in follow up visits and outpatient physical therapy (Figure 1).

The mean age of women was 56.5 years ( \pm 13.7 years). The mean BMI $\left(27.32 \mathrm{~kg} / \mathrm{m}^{2}\right)$ was considered above normal range, most women (55\%) were overweight or obese $\left(\mathrm{BMI}>25 \mathrm{~kg} / \mathrm{m}^{2}\right)$ and sixty-three percent $(63 \%)$ of women had surgical stage II and III. The most frequent surgery was radical mastectomy (54.4\%), followed by quadrantectomy (32.1\%) (Table 1).

The complications of dehiscence and scar tissue adhesion at the end of the fourth week after surgery were not significantly associated with any of the categories of preoperative BMI (Table 2).

During the first year after surgery, there were no significant differences between BMI categories and the frequency of scar tissue adhesion, pain, heaviness and lymphedema (Table 3 ).

There was no significant association between BMI categories and pain, scar tissue adhesion or heaviness in the upper limb, although in the second year after surgery the occurrence was lower in women with greater BMI. We observed that only the development of lymphedema had significant differences among categories of BMI ( $p=0.0268$ ) (Table 4). Almost $40 \%$ of obese women who returned to follow up in the second year after surgery developed lymphedema (Table 4). Analysing 
this complication, we found that obese women are 3.6 times more likely to develop lymphedema in the second year after surgery (OR 3.61 95\% CI 1.36 to 9.41 ) (data not shown in table).

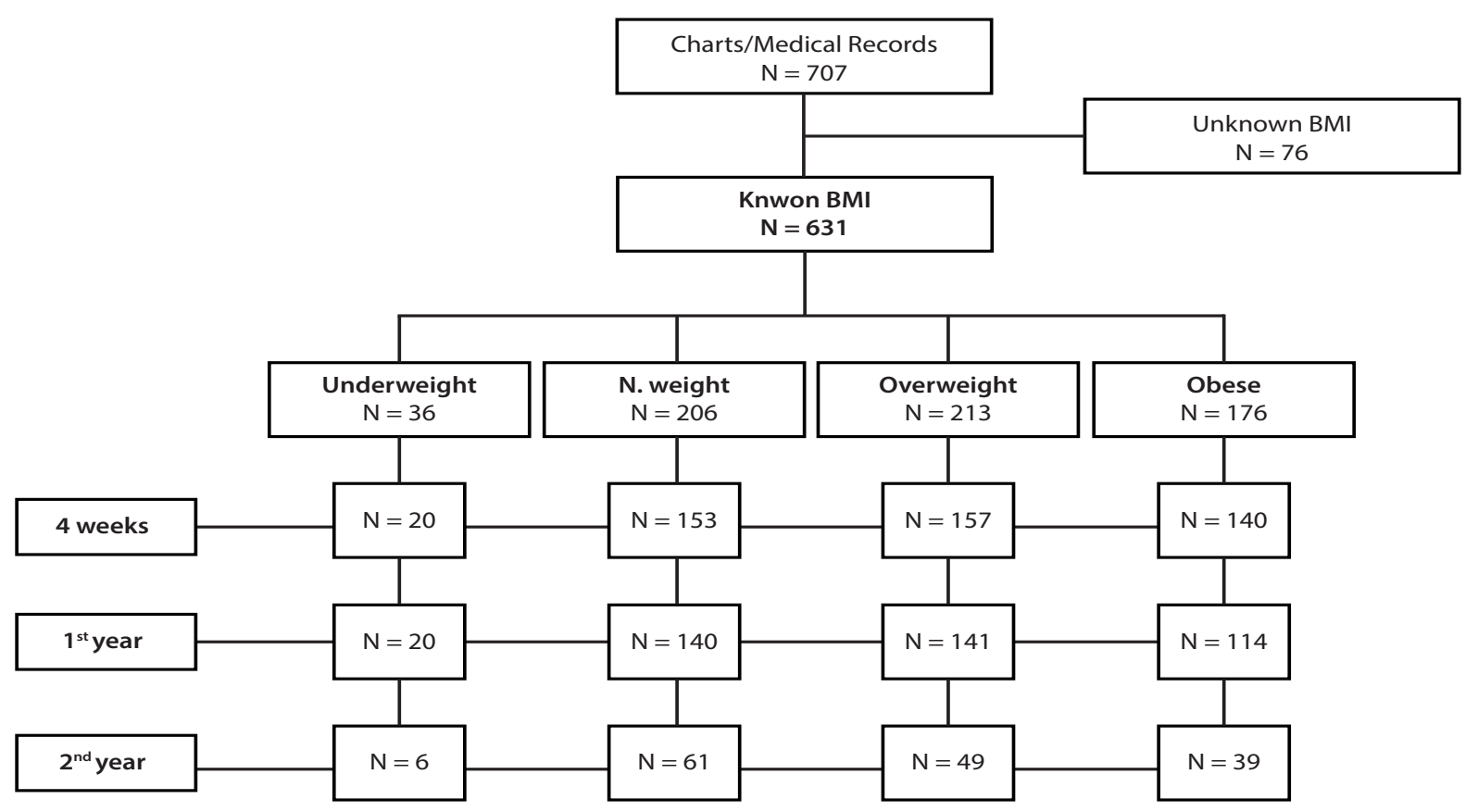

Figure 1. Number of medical records in the first two years after surgery for breast cancer

Table 1. Surgical and epidemiological characteristics of women

\begin{tabular}{|c|c|c|c|c|}
\hline \multirow{2}{*}{ Variables } & \multicolumn{4}{|c|}{$\mathrm{N}$ total $=707$} \\
\hline & $\mathbf{N}$ & Mean & SD & $(\%)$ \\
\hline Age & & 56.5 & 13.7 & \\
\hline Weight & & 67.85 & 13.86 & \\
\hline Height & & 1.58 & 0.07 & \\
\hline BMI & & 27.32 & 5.2 & \\
\hline underweight & 36 & & & $(5.1)$ \\
\hline normal range & 206 & & & $(29.1)$ \\
\hline overweight & 213 & & & (30.1) \\
\hline obese & 176 & & & $(24.9)$ \\
\hline unknown & 76 & & & $(10.7)$ \\
\hline \multicolumn{5}{|l|}{ Clinical Stage } \\
\hline is -1 & 228 & & & $(32.2)$ \\
\hline$\|-\| I$ & 445 & & & $(62.9)$ \\
\hline IV & 22 & & & (3.1) \\
\hline unknown & 12 & & & $(1.7)$ \\
\hline \multicolumn{5}{|l|}{ Surgeries } \\
\hline margin ampliation & 5 & & & $(0.7)$ \\
\hline quadrantectomy + SLB & 121 & & & (17.1) \\
\hline quadrantectomy + AD & 106 & & & (15) \\
\hline$M+S L B$ & 46 & & & (6.5) \\
\hline$S M$ & 31 & & & $(4.3)$ \\
\hline$S M+A D$ & 13 & & & $(1.8)$ \\
\hline MMRM & 186 & & & $(26.3)$ \\
\hline PMRM & 189 & & & $(26.7)$ \\
\hline HRM & 10 & & & $(1.4)$ \\
\hline
\end{tabular}

BMI: body mass index; Is: in situ; M: mastectomy; SLB: sentinel lymphonode biopsy; SMS: simple mastectomy; AD: axillary dissection; MMRM: Madden modified radical mastectomy; PMRP: Patey modified radical mastectomy; HRM: Halsted radical mastectomy 
Table 2. Complications according to BMI categories after 4 weeks of surgery

\begin{tabular}{lccccccccc} 
& \multicolumn{2}{c}{ Under weight } & \multicolumn{2}{c}{ Normal range } & \multicolumn{2}{c}{ Overweight } & \multicolumn{2}{c}{ Obese } & p value \\
& $\mathrm{n}=\mathbf{2 0}$ & $(\%)$ & $\mathrm{n}=153$ & $(\%)$ & $\mathrm{n}=157$ & $(\%)$ & $\mathrm{n}=140$ & $(\%)$ & $(24.3)$ \\
Dehiscence & 3 & $(15)$ & 29 & $(18.8)$ & 40 & $(25.5)$ & 34 & 0.4093 \\
Adhesion & 6 & $(30)$ & 55 & $(35.7)$ & 58 & $(36.9)$ & 43 & $(30.7)$ & 0.6634
\end{tabular}

Chi-square test

Table 3. Complications according to BMI categories in the 1st year after surgery

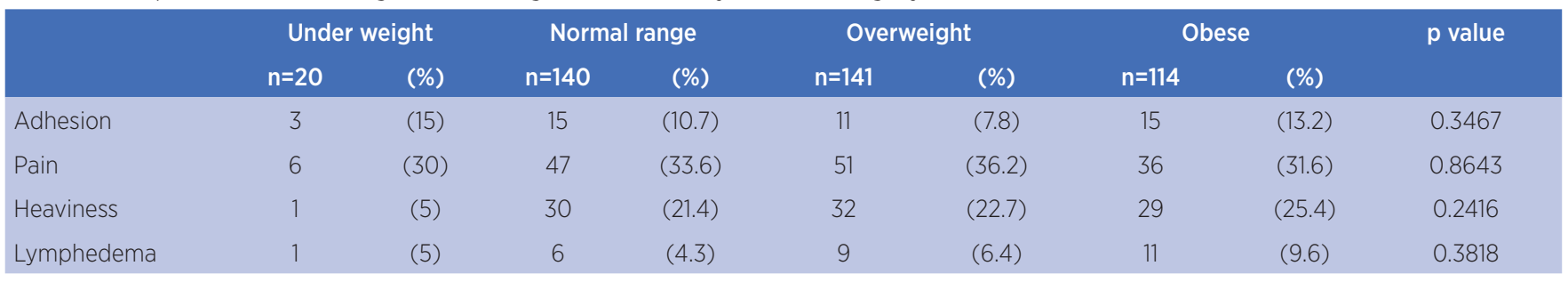

Chi-square test

Table 4. Complications according to BMI categories in the second year after surgery

\begin{tabular}{lccccccccc} 
& \multicolumn{2}{c}{ Under weight } & \multicolumn{2}{c}{ Normal range } & \multicolumn{2}{c}{ Overweight } & \multicolumn{2}{c}{ Obese } & p value \\
& $\mathrm{n}=6$ & $(\%)$ & $\mathrm{n}=61$ & $(\%)$ & $\mathrm{n}=49$ & $(\%)$ & $\mathrm{n}=39$ & $(\%)$ & $(2.6)$ \\
Adhesion & 1 & $(16.7)$ & 6 & $(9.8)$ & 6 & $(12.2)$ & 1 & 0.2529 \\
Pain & 3 & $(33.3)$ & 32 & $(52.5)$ & 18 & $(36.7)$ & 20 & $(51.3)$ & 0.3031 \\
Heaviness & 3 & $(50)$ & 23 & $(37.7)$ & 18 & $(36.7)$ & 22 & $(56.4)$ & 0.2199 \\
Lymphedema & 0 & $(0)$ & 9 & $(14.8)$ & 13 & $(26.5)$ & 15 & $(38.5)$ & 0.0268
\end{tabular}

Fisher's exact test

\section{DISCUSSION}

Up to one year after surgery for breast cancer, the different categories of BMI were not related with increased risk of developing scar tissue or UL complications. However, when evaluating women 6 and 12 months after surgery for breast cancer, Kwan et al (2010) observed a predictive relationship between the emergence of one or more complications of UL, such as pain, lymphedema and functional impairment with loss of range of motion, and high $\mathrm{BMI}^{5}$. There are no studies in the literature that evaluate the influence of $\mathrm{BMI}$ on dehiscence, pain and tissue adhesion.

In the second year after surgery, women either overweight or obese had higher rates of lymphedema, while the other complications analyzed did not correlate with BMI. Among many factors associated with the development of lymphedema, surgery and radiotherapy are worth mentioning ${ }^{12}$. However, women who at diagnosis are obese or who gain weight after the onset of breast cancer may be at increased risk for lymphedema ${ }^{6,8,13-16}$.

A study observed that women with BMI $>30 \mathrm{~kg} /$ $\mathrm{m}^{2}$ had two-times greater risk for lymphedema and multivariate analysis revealed that women with this category of preoperative BMI had a 2.93 greater chance of developing lymphedema compared to those with BMI $<25 \mathrm{~kg} / \mathrm{m} 2$ (95\% CI 1.03-8.31) ${ }^{7}$. The same was observed in a study of 997 women diagnosed with invasive breast cancer, of which 133 had lymphedema and were overweight at diagnosis of the disease with elevated risk for this complication (hazard ratio, 1.43, 95\% CI, 0.88-2.31) .

In agreement with the literature, this study demonstrated that at the end of the second year, almost $40 \%$ of obese women at follow up visit had lymphedema. As for heaviness in the UL reported by the patients, this number increased to $56 \%$.

It is not completely clear whether increased BMI is a direct risk factor for the development of lymphedema and two possible explanations for the observed influence of obesity on the development of lymphedema are: (a) in survivors of breast cancer with damage to the lymphatic system, the additional demand created by increasing body fat mass causes an imbalance between the volume of fluid and the lymphatic transport capacity ${ }^{5,8,17}$; and (b) increased endocrine response, that is, increased secretion of peptides, may contribute to lymphedema 
and tissue inflammation of the limbs of women at risk ${ }^{18}$. Surgery may also need to be more extensive as a result of the presence of adipose tissue and therefore more destructive to the lymphatic system ${ }^{8}$.

Obesity may not be a direct risk factor for developing lymphedema, but may be a risk for infections, scarring disorders (delayed healing, seroma, and fat necrosis), lymphangitis and lymphatic obstruction ${ }^{19}$. According to Ahemed et al. (2011) diseases that affect circulation such as coronary artery disease, hypertension or diabetes mellitus may increase lymphedema or symptoms in the upper limbs. However, after adjustment for obesity, there are no associations individually or collectively with these comorbidities ${ }^{6}$.

There is little information about the determinants of lymph flow, and thus further studies on lymphatic drainage and impedance should be performed to accurately determine the precise pathogenesis of lymphedema in obesity ${ }^{7}$.

The diagnosis of advanced cancer seems to have an influence on the onset of lymphedema. It was observed in this study that more than $60 \%$ of women studied presented an advanced stage of cancer and lymphedema, a result consistent with literature. In prospective cohort study of 1287 women, 104 (8\%) developed lymphedema, 475 (37\%) presented arm symptoms without a diagnosis of lymphedema and 708 (55\%) did not present lymphedema. It was observed that in addition to the signs of more advanced cancer (locally advanced or nodal didease) and their treatment (greater number of lymph nodes removed and chemotherapy), there are modifiable characteristics associated with behaviours that increased risk of lymphedema and related symptoms, in particular, obesity and poor general health status ${ }^{6}$.

Hayes et al. (2008) point out that a sedentary lifestyle (OR, 1.9, 95\% CI, 0.6-5.5) is associated with higher risk of lymphedema ${ }^{20}$, on the other hand several studies point out that signs and symptoms did not increase with exercise ${ }^{21}$. Therefore, it is safe for women treated for breast cancer to engage in physical activity ${ }^{22}$.

A review on clinical trials concluded that carefully controlled physical activity does not alter the risk for occurrence or worsen the symptoms of lymphedema and may be a strategy to reduce obesity and improve women's overall health and quality of life when treated for breast cancer ${ }^{23}$.

The following may limit this study: the exclusion of 76 records that did not present weight and height data to calculate BMI, not all women adhere to the Rehabilitation Program, the number of different follow up visits, the evaluations made by different physical therapists and the retrospectively data collection, which made it difficult to obtain data relatied to adjuvant treatments.

This study shows that approach to preoperative patients with breast cancer should be focused on weight control. Moreover, implement strategies for late followup of these women in order to prevent lymphedema.

\section{CONCLUSION}

Women with BMI $\geq 25 \mathrm{~kg} / \mathrm{m}^{2}$ prior to surgery for breast cancer have a greater risk for developing lymphedema in the second year after surgery. The incidence of other complications such as pain, tissue adhesions, dehiscence, and heaviness in UL were not influenced by BMI.

\section{REFERENCES}

1. Chan DN, Lui LY, So WK. Effectiveness of exercise programmes on shoulder mobility and lymphoedema after axillary lymph node dissection for breast cancer: systematic review. J Adv Nurs. 2010; 66(9): 1902-14.

2. Mols F, Vingerhoets AJ, Coebergh JW, van de Poll-Franse LV. Quality of life among long-term breast cancer survivors: a systematic review. Eur J Cancer. 2005; 41(17): 613-9.

3. Hack TF, Kwan WB, Thomas-MacLean RL, Towers A, Miedema $B$, Tilley A, et al. Predictors of arm morbidity following breast cancer surgery. Psycho-Oncol. 2010; 19: 1205-12.

4. Devoogdt N, Van Kampen M, Christiaens MR, Troosters T, Piot W, Beets N, et al. Short. - and long-term recovery of upper limb function after axillary lymph node dissection. Eur J Cancer Care. 2011; 20: 77-86.

5. Kwan ML, Darbinian J, Schmitz KH, Citron R, Partee P, Kutner SE, Kushi LH. Risk factors for lymphedema in a prospective breast cancer survivorship study: the pathways study. Arch Surg. 2010; 145(11):1055-63.

6. Ahmed RL, Schmitz KH, Prizment AE, Folsom AR. Risk factors for lymphedema in breast cancer survivors, the lowa Women's Health Study. Breast Cancer Res Treat. 2011; 130(3): 981-91.

7. Helyer LK, Varnic M, Le LW, Leong W, McCready D. Obesity is a risk factor for developing postoperative lymphedema in breast cancer patients. Breast J. 2010; 16(1): 48-54.

8. Ridner SH, Dietrich MS, Stewart BR, Armer JM. Body mass index and breast cancer treatment-related lymphedema. Support Care Cancer. 2011; 19: 853-7.

9. Savetsky IL, Torrisi JS, Cuzzone DA, Ghanta S, Albano NJ, Gardenier JC, Joseph WJ, Mehrara BJ. Obesity increases 
inflammation and impairs lymphatic function in a mouse model of Iymphedema. Am J Physiol Heart Circ Physiol. 2014; 15; 307(2).

10. World Health Organization (WHO). Obesity and overweight. Fact sheet № 311. 2006. Available in: http://www.who.int/ mediacentre/factsheets/fs311/en/index.html. Accessed in: 3th, February, 2015.

11. Asim M, Cham A, Banerjee S, Nancekivell R, Dutu G, McBride C, Cavanagh S, Lawrenson R, Campbell I. Difficulties with defining lymphoedema after axillary dissection for breast cancer. N Z Med J. 2012; 125(1351): 29-39.

12 Oliveira MM, Gurgel MS, Miranda MS, Okubo MA, Feijó LF, Souza GA. Efficacy of shoulder exercises on locoregional complications in women undergoing radiotherapy for breast cancer: clinical trial. Rev Bras Fisioter. 2009; 13: 136-43

12. Lee TS, Kilbreath SL, Refshauge KM, Herbert RD, Beith JM. Prognosis of the upper limb following surgery and radiation for breast cancer. Breast Cancer Res Treat. 2008; 110(1): 19-37.

13. Meeske KA, Sullivan-Halley J, Smith AW, McTiernan A, Baumgartner KB, Harlan LC, et al. Risk factors for arm lymphedema following breast cancer diagnosis in black women and white women. Breast Cancer Res Treat. 2009; 113(2): 383-91.

14. Paskett ED, Naughton MJ, McCoy TP, Case LD, Abbott JM. The epidemiology of arm and hand swelling in premenopausal breast cancer survivors. Cancer Epidemiol Biomarkers Prev. 2007; 16 (4): 775-82.

15. Koul R, Dufan T, Russell C, Guenther W, Nugent Z, Sun X, et al. Efficacy of complete decongestive therapy and manual Iymphatic drainage on treatment-related
Iymphedema in breast cancer. Int J Radiat Oncol Biol Phys. 2007; 1; 67(3):841-6.

16. Nesvold IL, Dahl AA, Løkkevik E, Mengshoel AM, Fossa SD. Arm and shoulder morbidity in breast cancer patients after breast-conserving therapy versus mastectomy. Acta Oncologic. 2008; 47: 835-42.

17. Soran A, D’Angelo G, Begovic M, Ardic F, Harlak A, Samuel Wieand $\mathrm{H}$, et al. Breast cancer-related lymphedema: what are the significant predictors and how they affect the severity of lymphedema? Breast J. 2006; 12(6): 536-43.

18. Stanton A, Holroyd B, Mortimer P, Levick J. Comparison of microvascular filtration in human arms with and without postmastectomy oedema. Exp Physiol. 1999; 84: 405-19.

19. Mak SS, Yeo W, Lee YM, Mo KF, Tse KY, Tse SM, et al. Predictors of lymphedema in patients with breast cancer undergoing axillary lymph node dissection in Hong Kong. Nurs Res. 2008; 57(6): 416-25.

20. Hayes SC, Janda M, Cornish B, Battistutta D, Newman B. Lymphedema after breast cancer: incidence, risk factors, and effect on upper body function. J Clin Oncol. 2008; 26(21): 3536-42.

21. Lane K, Worsley D, Mckenzie D. Exercise and the lymphatic system. - implications for breast-cancer survivors. Sport Med. 2005; 35(6): 461-71.

22. Bicego D, Brown K, Ruddick M, Storey D, Wong C, Harris SR. Exercise for women with or at risk for breast cancer-related Iymphedema. Phys Ther. 2006; 86(10): 1398-405.

23. Schmitz KH, Ahmed RL, Troxel A, Cheville A, Smith R, LewisGrant $L$, et al. Weight lifting in women with breast cancerrelated Iymphedema. N Engl J Med. 2009; 361(7): 664-73 